\begin{tabular}{lc}
\hline A N N A L E S \\
UNIVERSITATIS MARIAE CURIE-SKŁODOWSKA \\
LUBLIN - POLONIA \\
VOL. XXVI, 2 & SECTIOK
\end{tabular}

2019

University of Málaga (Spain), Faculty of Arts

University of Jyväskylä (Finland), Faculty of Humanities and Social Sciences

FRANCISCO J. BELLIDO

ORCID ID: https://orcid.org/0000-0002-5250-0053

\title{
Democracy in Constituent Moments: Exploring the Spanish Constitutional Debate of 1931 through Political Theory and Conceptual History*
}

\begin{abstract}
This paper aims to answer the question of why constituent moments are relevant to political theory. It hypothesises the Spanish constitutional debate of 1931 as a case of conceptual innovation in parliamentary politics by arguing that debates in constituent moments entail a special kind of parliamentary argumentation when new political regimes are established. There, all sorts of theoretical, normative, historical, and institutional aspects are discussed to deliberate on the future character and functioning of a political regime. From a methodological point of view, this analysis draws on the revision of arguments and political terms used by MPs during the Spanish constituent assembly of 1931. The first part of the article emphasises the potentiality of constitutional debates for political theory and conceptual history, the two following chapters contextualise the historical and intellectual keys of 1931 Spain, the fourth and final part briefly explains two cases of conceptual controversy around the terms "state" and "sovereignty". Based on the evidence provided by this study, the article concludes that the Spanish constitutional debate of 1931 is a fertile case to explore conceptual innovation of interwar legal and political theory.
\end{abstract}

Key words: constituent moments, Spanish constitutional debate of 1931, conceptual innovation, political theory

* This research is supported by an FPU pre-doctoral grant from the Spanish Ministry of Education. This article has been prepared in the framework of the research project "Civic Constellation III: Democracy, Constitutionalism and Anti-Liberalism”, PGC2018-093573-B-100 (2019-2022). I would like to thank the reviewers for the comments made to improve the final version. 


\section{INTRODUCTION}

Constitutional debates contain a wide range of legal expertise and intellectual references anchored in the history of political thought. Divergent and opposite views about the state, political and civil rights, together with the rationale of public policies, are reflected in parliamentary deliberations. As a direct consequence, contested new meanings of classic political concepts arise. Unlike regular parliamentary debates, intellectual references that are embedded in constitutional debates at parliamentary settings connect national with international experiences in constitution-making involving rhetorical resources, public law and political theory arguments regarding the foundations of a political regime.

The practice of constitutional debates demands "borrowing, learning and accommodation, but also moments of creative innovation and experimentation". The mixture of mythical elements rooted in the national history of a country with political values and comparative legal experiences demonstrate that "constitutional design is nothing if not audacious" [Ginsburg 2012: 1-3]. MPs enrich parliamentary deliberations by usually introducing a variety of political concepts and arguments in innovative ways. Therefore, this analysis takes the debates of the Spanish constitutional debate of 1931 as both a basic source for lawmaking in the building of democratic regimes and a case of conceptual innovation in the use of classic political concepts and ideas. In doing so it examines some of the central topics of political theory, namely, freedoms, rights, the state, legitimacy, justice or property, among others.

These topics of political theory in constitutional debates combine the perspective of legal expertise provided by MPs with the role of parliaments as assemblies for political deliberation. Hence, parliaments are relevant to political theory or philosophy insofar as they provide the basic intellectual context of public deliberations. Constitutional debates show how theoretical pondering over, for example, the acknowledgement of individual liberties, the limits to state action, the broadening of social rights or, more generally, the use of political concepts and ideas proceeds in political deliberations.

Institutional design in constitution-making periods is never resolved definitely. Rather, constitutional debates open to public debates all kinds of ideological disagreements that are common to parliamentary politics. Dissent is not relegated to sidelines, but is a constitutive aspect of parliamentary activity where opposed views become "a condition for a thorough understanding of the question" [Palonen 2019: 46].

This analysis combines political theory, conceptual history and parliamentary history as three complementary approaches. As interdisciplinary basis to study the constitutional debate of 1931, it assumes that political concepts are dependent from both the institutional context and those deliberations in which they appear. Therefore, conceptual originality in the use of political terms is always produced as a consequence of multiple contested political choices publicly debated.

Examining political theory or philosophy resources (ideas, theories, arguments, controversies) in parliamentary debates of constituent moments has barely been researched in 
the case of $20^{\text {th }}$-century Spain. This analysis focuses on the debates held around religious freedom, the structure of the state, the aim given to reformist policies or the extension of social rights, among others. In doing so, it highlights the contested meanings of central concepts such as state, constitution, sovereignty or reform through the revision of the political arguments raised by MPs and the analysis made by journalists and scholars.

\section{THE CONTEXT OF THE CONSTITUTIONAL DEBATE OF 1931}

This study looks into a constituent moment that receives the influences of interwar trends of constitutional theory and political philosophy. Democratic socialism, centre-right liberalism and traditionalist conservatism can be identified as the three main ideological influences in Parliament. The division of parties between left and right was clear from the very beginning of constitutional debates, with the exception of the Group in the Service of the Republic. This party was composed by intellectuals such as the philosopher José Ortega y Gasset and the writer and journalist Ramón Pérez de Ayala, whose intellectual affinities were plural.

Briefly said, the Spanish Socialist Workers' Party and the Republican Action Party represented democratic socialism; the Radical Republican Party, the Progressive Republican Party, the Democratic Liberal Republican Party and some agrarian MPs represented classic liberalism; the Basque-Navarre Minority and the Popular Agrarian Minority regarded Spanish traditionalism as the answer against wide reformist policies by the coalition government, even if some agrarian representatives were in favour whether of imitating or improving the Spanish Constitution of 1876.

As case study, the constitutional debate of 1931 illustrates why political discussions in constituent moments, shaping the structure and functioning of the state, are the key to building a democratic regime. The variety of opposed arguments reveals innovative uses of political concepts by MPs, intellectuals and journalists, and a fruitful path to frame the constitutional principles of a new state.

The democratic republic that resulted from the passing of the Constitution of 1931 is understood by its protagonists in different, sometimes incompatible, ways. Among left-wing representatives, it means the break with the Spanish tradition associated with despotism by founding an ambitious democratic state with extensive competences on social and economic issues. Among liberal and conservative parties, instead, the new democratic Constitution is an instrument to assure the permanence of the republican regime through gradual reforms. Moderate left-wing representatives tackled the issue of the democratic nature of the republic since the inaugural address of the leader of the Constitutional Committee, Luis Jiménez de Asúa. He emphasises the principles of the constitutional project as being "full of the living political blood provided by democratic veins" [DSCCRE 27 August 1931: 644].

The political context is relevant to understand the atmosphere of the constitutional debate. The dictatorship of general Miguel Primo de Rivera (1923-1930) is 
followed by two short-lived monarchic cabinets, namely those of Lieutenant General Dámaso Berenguer and Admiral Juan Bautista Aznar. On 12 April 1931, Bautista Aznar's "concentration government" calls local elections whose results in the cities were favourable to republican parties, whereas in rural areas monarchic candidates obtained a large majority of the vote [Tusell 2004: 240-242].

Aznar's cabinet, King Alfonso XIII, and republican supporters take these elections as a plebiscite on the monarchy, hence the results meaning a serious questioning of the regime. On 14 April 1931, a republic is proclaimed in the streets of the cities of Vigo, Éibar, San Sebastián, Valencia and Barcelona. Count of Romanones, state minister, advises Alfonso XIII to resign. The king agrees and a provisional, prorepublican government is established [Gil Pecharromán 1989: 28]. This coalition government calls general election for 28 June 1931.

The distribution of parliamentary seats (470) is hard to clarify since some parties modified their names and some elected representatives changed parties after the general election. These circumstances also explain the weakness of the party system in Spain in 1931 [Tusell 1982: 160]. Despite them, gathering the information collected by historian Javier Tusell from provinces, it is possible to itemise the results as follows: Spanish Socialist Workers' Party (115), Radical Republican Party (90), Radical Socialist Republican Party (63), Republican Left of Catalonia (29), Republican Action Party (26), Progressive Republican Party (25), Popular Agrarian Minority (24), Autonomous Galician Republican Organization (16), Federal Republican Party (16), Group in the Service of the Republic (13), Basque-Navarre Minority (11), other minority groups under $2 \%$ of seats and independent MPs (42) [Tusell 1982: 161-196]. ${ }^{1}$

The provisional government hurriedly adopted rules of procedure, agreed only one month before the beginning of the constituent sessions. They set up clear procedural principles for discussing motions through sixty-four articles published as decree in the state's official journal ["Gaceta de Madrid" 12 July 1931:341]. These principles became a resource for minority groups in Parliament to act as the real opposition to the government. The parliamentary procedure aimed to reasonably regulate debates by fixing a set of rules which parties in the opposition could accept. Even if it was not passed by Parliament, the official procedure served to channel deliberative sessions offering minority parties the chance to actively participate: MPs' speeches were assigned irrespective of the number of seats obtained by parliamentary groups. MPs' turns were confirmed after parties asked to speak. Then, the order of formal petitions to the speaker (presidente) of Parliament was the criterion for deciding speeches.

Before the constitutional debate begins and elections are held, on 6 May 1931, the provisional government sets up a Legal Advisory Committee to make the preliminary

\footnotetext{
$1 \quad$ Tusell uses different acronyms for naming the same political parties. Particularly, he distinguishes Basque Nationalist Party from Traditionalist Communion since they were different parties. Here I classify both parties together in the Basque-Navarre Minority, which worked as a single minority group in Parliament.
} 
draft of the Constitution. At the end, the preliminary draft is rejected by Parliament on 6 July 1931, being considered a conservative draft by left-wing representatives. On 28 July of that year, a new Constitutional Committee, including 21 members, led by the socialist MP Luis Jiménez de Asúa, revises that first document. The new draft is closer to the demands of left-wing parties and it is finally accepted to be discussed in Parliament [Juliá 2009: 42-43], bringing forward the ideological division in the chamber.

Rival theses about Spanish and European history made visible two alternatives over lawmaking: the first of them, opposition MPs argue, has a moderate character that improves the parliamentary tradition of $19^{\text {th }}$-century Spain without breaking the historical ties with it; the second of them, shared by a large majority of the coalition government, conceives of the newborn democratic regime as an opportunity for entirely renewing the country's institutions, breaking at the same time with conservative constitutionalism and Spanish traditionalism. Republican MPs portray themselves as heirs to Cádiz's liberal constituents to continue their unfinished revolutionary endeavours with the aim of building a society of equal civil and political rights [González Calleja, Cobo Romero, Martínez Rus, Sánchez Pérez 2015: 11].

\section{HISTORICAL AND INTELLECTUAL INFLUENCES ON THE SPANISH CONSTITUTIONAL DEBATE}

Interwar democratic experiences of constitution-making in Europe and some countries in America, mainly Mexico (1917), are influential in the Spanish debate of 1931. The course of the debate is also determined by the social and political circumstances of the new regime, a republic, that was aimed to replace General Miguel Primo de Rivera's dictatorship: partisan fragmentation in Parliament, together with $86 \%$ of MPs lacking political experience in national politics, economic instability, and the mobilisation of masses through trade unions, among others. The debate of 1931 reflects these features by means of a renewed and polysemic political language inspired by other constitutional experiences, especially those of Weimar (1919) and Austria (1920).

The Weimar Constitution is the main example for Spanish left-wing MPs. The broadening of social rights in the Constitution of 1931 aims to protect workers against exploitation, to provide social welfare, to universalise the access to primary education and to secure that justice is free for those economically needy. The social orientation of the first republican government (April 1931 - November 1933) demands budgetary plans that are difficult to assume since the economic circumstances of the country worsen over that time span.

Tensions between left-wing and right-wing MPs during the debate run parallel to the inner conflicts in the coalition government. Right-wing conservative MPs are opposed to any kind of secularisation by the state, whereas anticlerical movements 
intensify their activity in the streets. Moderate centre-right and centre-left MPs argue in favour of realistic reformist policies that can be accepted by a large majority of society without paralysing the economic capacity of the state. However, they hold a very reduced influence due to their low number of seats in Parliament.

The Spanish Socialist Workers' Party together with left-wing and centre radicals agree on ambitious reformist policies extending the competences of the state if supported by a majority of MPs in Parliament, as it finally happened. Property rights and religious freedom are key issues in the constitutional agenda, which is especially rich from an argumentative perspective but also divisive for eventual agreements. MP Álvaro de Albornoz (Radical Socialist Republican Party) summarises that cleavage between right-wing and left-wing parties by rejecting any possible agreement: "I also hear to say that a constitution is always a transaction, a compromise among parties. I do think that such a view is totally wrong, because I do not know any political constitution that had been an agreement among the different parties" [DSCCRE 7 October 1931: 1561].

Some sessions during the months of September, October and November 1931 give rise to a high number of political concerns that are the result of sui generis interpretations of interwar constitutionalism by Spanish constituent members. Leading MPs such as the socialists Julián Besteiro and Fernando de los Ríos (both belonging to the Spanish Socialist Workers' Party) were acquainted with German and French constitutional theory. De los Ríos, for instance, translated Georg Jellinek's writings into Spanish. Among conservative MPs, José María Gil-Robles (Popular Agrarian Minority), Antonio Royo Villanova (Popular Agrarian Minority) and Ángel Ossorio y Gallardo (independent) had a large education in French administrative law to the extent of making some well recognised academic contributions in the field.

Royo Villanova mentions the legacy of the French public law scholar Léon Duguit to emphasise the parliamentary nature of the new democratic regime:

I think that the republic should be frankly parliamentary. I understand that Parliament, with all its faults, is the highest guarantee of freedom and discussion; and not certainly because of the political reason that it can better respond to national sovereignty, but because what a French writer, certainly far from parliamentary superstition, follower of the school of the famous Duguit, calls, reason of legal technique [DSCCRE 23 October 1931: 644].

Democracy and parliamentarism are considered coterminous in Europe before World War II. The idea of parliamentarism is addressed as the ideal state form of European democracies. The opposite term is "antidemocracy". In the interwar period, dictatorship and models of direct democracy are usually taken as threats to parliamentary democracy [Aragón Reyes 1996: 58]. Also in the Spanish constitutional debate this identification of Parliament and democracy occurs, as Royo Villanova's words highlight. 
In $20^{\text {th }}$-century Spain, anti-parliamentarism is first represented by Miguel Primo de Rivera's dictatorship, whose critics against the $19^{\text {th }}$-century Spanish representative system find supporters among the national press, as Víctor Pradera in the monarchic newspaper "ABC" [Cuenca Toribio 1995: 252-253]. After the fall of the dictatorship and the proclamation of the republic in the streets, only traditionalist movements are openly unparliamentary and antidemocratic. Parliamentarism, instead, gains relevance. In the Spain of that time, the term means two different realities: on the one hand, parliamentarism is a synonym for parliamentary system of government, where government and Parliament cooperate with each other; on the other hand, it denotes a representative regime in a wider sense [Fernández Sarasola 2009: 249].

\section{CONCEPTUAL CONTROVERSIES OVER STATE AND SOVEREIGNTY}

MPs discuss the role of the state along constitutional sessions. "State" and "sovereignty" are key terms in the large majority of deliberations in Parliament between September and November 1931. According to the analysis of Juan F. García Santos, adjectives such as "monarchic", "old", "republican", "liberal", "legal", "bourgeois", "socialist" and "Soviet" become terms associated with the idea of state during the Spanish Second Republic (1931-1939) [García Santos 1980: 440]. Here, I briefly select some parliamentary controversies held in September 1931 over the ideas and models of sovereignty and state.

It is significant that in the first years of the Spanish Second Republic, some jurists leave aside both Krausism and legal liberalism with the aim of building a renewed political science. Political law of German roots reinforces the legal technique of positivism through the role of legislators [Gordillo Pérez, Martín, Vázquez Alonso 2017: 54]. This context provides a fertile field for Spanish constituent representatives to deliberate on the traditional meanings of "state" and "sovereignty".

Influences of German and French models on Spanish MPs are sometimes translated into the language of two opposite historical models. Thus, the centrist MP Ricardo Samper (Radical Republican Party) distinguishes a historical German state based on the idea of state's power from the national and progressive model of France:

Between the state-power of the German historical type, that unleashed the European war, and the nation state which is practised in France, I declare in favour of the nation state. And I think, after all, that the state is no more than a management of public services, and that individual rights and freedoms are above the state and cannot be constrained except when it is required by living together and the coordination with the law and the freedom of the other citizens [DSCCRE 11 September 1931: 871].

The idea of national sovereignty is contested during the constitutional debates, whereas popular sovereignty is widely accepted among left-wing and right-wing par- 
ties, with the exception of some traditionalists. For instance, Mariano Ruiz-Funes, of the Republican Action Party, understands popular sovereignty as the source of public powers. He stands against the idea that democratic power is the result of agreements between political parties: "We had to define in the Constitution what was the origin of power in a democratic republic. It was not a superior origin, it was not one of agreed nature, but an eminently popular one" [DSCCRE 11 September 1931: 882].

Among federalist representatives, Joaquín Pi y Arsuaga, of the Federal Republican Party, argues against the idea of national sovereignty. He matches national sovereignty to antidemocratic practices of monarchs and to the malfunction of the division of state powers:

We do believe that the sovereignty of the nation is something which resembles the sovereignty of kings. It was that thing about the rule of everyone by a single one. National sovereignty means the denial of democracy, of the rule of the people by the people. And it is also a denial of the division of powers between the legislative, the executive and the judiciary. They have to be completely autonomous, since that autonomy avoids the meddling of one of the powers in the rest, which we think is possible [DSCCRE 15 September 1931: 922].

According to Luis Araquistáin, of the Spanish Socialist Workers' Party, the concept of sovereignty is also central to the distribution of competences between the state and the regions. He understands "autonomy" and "sovereignty" as close terms, referring the latter to the capacity of regions, especially Catalonia, to assume competences without the interference of the state:

All the confusion, all the blindness, all the excitement around the autonomy of Catalonia comes from a misinterpretation, by most of the Spanish people, of a concept stressed in the writings and discussions of Catalans: the concept of sovereignty. We want, partisans of autonomy say, to draw the limits, the political frontiers, to note the "extension" of our sovereignty. But within those limits, frontiers and extensions, we aim to be the highest. We need an "intensive" sovereignty, without nation state's interferences. This is the basic thesis of Catalan autonomy [Araquistáin 1930: 124].

Some right-wing MPs, such as Juan Castrillo, of the Progressive Republican Party, agree to coordinate autonomy and sovereignty in the case of autonomous regions: "As I understand it, there is no weakening of sovereignty. There is a full and decisive statement of autonomies. There where autonomy arises, it necessarily rises up a joint participation [of the state and the region] in the sovereignty" [DSCCRE 22 September 1931: 1040].

The meanings given to state and sovereignty along the constitutional sessions are connected with the different issues covered in the parliamentary agenda (from the separation between church and state to the decentralisation of competences in 
the hands of the regions). Nevertheless, both terms remain central to understanding how constituent representatives reinterpreted European public law to build the basis of Spanish democracy.

\section{CONCLUSIONS}

In this article, I have firstly introduced some remarks to the study of constitutional debates applying methodological resources of political theory or philosophy and conceptual history. Secondly, I have selected the Spanish constitutional debate of 1931 as a special moment where the building of a democratic regime, after a seven -year dictatorship, provides a fertile ground for the development of new meanings of classic political concepts. Thirdly, the article has examined the main historical and intellectual influences that the constituent representatives had. Finally, by way of example, I have presented some ideological controversies over the meanings of "state" and "sovereignty" risen in the parliamentary sessions of September 1931.

The article has argued that constitutional debates are a valuable resource to studying political theory and conceptual history. The Spanish case illustrates how classic political concepts are rhetorically redefined in connection with interwar legal and political theory. Far from being a mere sophistry, the arguments held by MPs aid to reveal decisive conceptual changes in the use of key political concepts. From a transnational perspective, it provides the basis to compare the Spanish process of constitution-making in 1931 with other constituent moments of interwar Europe.

\section{BIBLIOGRAPHY}

Aragón Reyes, M. 1996. Parlamentarismo y antiparlamentarismo en el primer tercio del siglo XX, "Revista de Estudios Políticos", No. 93.

Araquistáin, L. 1930. El ocaso de un régimen, España, Madrid.

Cuenca Toribio, J.M. 1995. Parlamentarismo y antiparlamentarismo, Congreso de los Diputados, Madrid.

Diario de Sesiones de la Cortes Constituyentes de la República Española (DSCCRE) [Proceedings of the Constituent Assembly of the Second Spanish Republic], https://app.congreso.es/est_sesiones/ (access: 30.05.2019).

Fernández Sarasola, I. 2009. Los partidos politicos en el pensamiento español: de la Ilustración a nuestros dias, Marcial Pons, Madrid.

García Santos, J.F. 1980. Léxico y política de la Segunda República, Universidad de Salamanca, Salamanca. Ginsburg, T. (ed.) 2012. Comparative Constitutional Design, Cambridge University Press, Cambridge. Gil Pecharromán, J. 1989. La Segunda República, Historia 16, Madrid.

González Calleja, E., Cobo Romero, F., Martínez Rus, A., Sánchez Pérez, F. 2015. La Segunda República Española, Pasado y Presente, Barcelona.

Gordillo Pérez, L., Martín, S., Vázquez Alonso, V. 2017. Constitución de 1931: estudios jurídicos sobre el momento republicano español, Marcial Pons, Madrid.

Juliá, S. 2009. La Constitución de 1931, Iustel, Madrid.

Palonen, K. 2019. Parliamentary Thinking: Procedure, Rhetoric and Time, Palgrave Macmillan, London. 
Reglamento Provisional de las Cortes Constituyentes [Provisional Rules of Procedure of the Constituent Assembly], "Gaceta de Madrid”, 12.07.1931, p. 341, https://www.boe.es/datos/pdfs/BOE//1931/193/ A00339-00344.pdf (access: 27.05.2019).

Tusell, J. 1982. Las constituyentes de 1931: unas elecciones de transición, Centro de Investigaciones Sociológicas, Madrid.

Tusell, J. 2004. El Directorio y la Segunda República: la dictadura de Primo de Rivera, el fin de la Monarquía y la República (1923-1936), Espasa Calpe, Madrid.

\section{BIOGRAPHY}

Francisco J. Bellido, a PhD candidate at the Universities of Málaga, Spain (philosophy) and Jyväskylä, Finland (political science), working with Prof. José María Rosales, and in Jyväskylä also with Dr. Hanna-Mari Kivistö and Dr. Taru Haapala. Graduated in philosophy in 2014, and completed two master's degrees. Between February and September 2018, received a pre-doctoral contract at the University of Málaga and since September 2018, a pre-doctoral FPU contract of the Spanish Ministry of Education. His two recent papers include: El debate constitucional de 1931 en España sobre la libertad de conciencia, "Eunomía. Revista en Cultura de la Legalidad", vol. 13 (2018) and the review A History of Justice Through Visual Metaphors, "Global Intellectual History", vol. 4 (2019). E-mail: franciscojavbellido@uma.es 